\title{
The Impact Of Private Label Sales Penetration On Category Profitability
}

Michael Pepe, Siena College, USA

\begin{abstract}
This study analyzes the impact that private label brands have on category profitability in supermarkets within the framework of category management. Category management seeks to enhance the overall performance of product categories as measured by profitability. Private label brands have dramatically increased in recent years in supermarkets with a key objective of improving category profitability.

This longitudinal study uses Point-of-Sale (POS) data from a supermarket retailer over three years consisting of 39 periods. Data is collected from ten product categories from the center store comprised of dry grocery, frozen foods, and refrigerated dairy. The results of this study indicate that in only two categories, a significant positive relationship existed between category private label sales penetration and category profitability.
\end{abstract}

Keywords: Category Management; Private Label; Supermarkets

\section{INTRODUCTION}

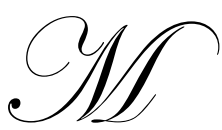

any supermarkets since the early 1990s have embraced a concept called category management with the objective of improving the overall performance of product categories and establishing consumer loyalty. This enhancement to category performance can result in numerous benefits to organizations seeking to increase profits in a competitive business environment.

The rapid proliferation of store brands is dramatically changing the competitive environment of supermarkets and is a major goal of category management. Private label brands comprised an all time high of 21.3\% of unit share and 16.4\% of dollar share in supermarkets in 2006 (PLMA yearbook, 2007). Between 1999 and 2003, private label products in supermarkets grew at an annual rate of $17.9 \%$ compared to national brand product sales growth of 14\% during the same time period (PLMA yearbook, 2004).

This study examines the impact of private label products on category profitability. Private label brands have become an important source of profits for supermarkets and a threat to national brand manufacturers (Quelch \& Harding, 1996). Due to their store brand programs, supermarkets have increased shelf space of their private brands at the expense of national brands. Private brands are among the top three brands in $70 \%$ of supermarket product categories and no other product brand has as much of a presence in as many categories (Hoch, 1996). Business surveys and business press reports consistently show that store brands are a top priority for grocery retailers (Alaimo, 2003; Wellman, 1997).

Due to their exclusivity, strong private labels boost store loyalty and gross margin opportunities may be greater (Levy \& Weitz, 2007). Private brands have emerged as a key weapon and have started to play an important role in the battle for control of the distribution channel and consumer loyalty (Patti \& Fisk, 1982). Large retailers are now realizing that effective marketing of store brands can increase store loyalty, chain profitability, and product turnover (Richardson et al., 1996). Increasing the sales penetration of their quality store brands improves profits for retailers. This is because store brands are store specific and, "when consumers exhibit a varying degree of inertia in brand switching, quality store brands make it more costly for consumers to switch stores and lead to greater retailer loyalty" (Corstjens \& Lal, 2000). Since private label brands typically carry a higher per unit margin than national 
brands by three to six percent, retailers have an additional incentive to sell their private brands (Garretson et al., 2002).

Unlike national brands which may be purchased at virtually any chain, store brands are proprietary to the chains themselves. Store brands provide several advantages in competing with national brands. First, supermarkets control the retail price of all brands offered in their stores so they can manage a price disparity that favors the store brand. Second, supermarkets might emulate various products that national brands have without spending too much in product and design development since they contract the production of store brands with manufacturers, who most of the time are the same companies that produce national brands (Velez, 2003). According to Quelch and Harding (1996), "More than $50 \%$ of U.S. manufacturers of branded consumer packaged goods make private label goods as well." Third, supermarkets decide which products will be sold in their stores as they are the owners of their outlets. Supermarkets also determine display space for products and decide how the products sold in the store are merchandised. Supermarkets can sell store brands at a lower price than national brands and still be more profitable and store brands represent one key point of difference among supermarkets (Velez, 2003).

Store brands and national brands are managed in many supermarkets within a framework known as category management. Category Management $(\mathrm{CM})$ is a retail management initiative aimed at improving the overall performance for a retailer in a product category through the coordination of buying, merchandising, and pricing of the brands in the category. According to an industry report, grocery retailer interest in category management is high with $83 \%$ viewing Category Management as the most important issue facing their company (Progressive Grocer, 1995). Category performance also has gained prominence in business practice as demonstrated by the significant resource commitment made by both manufacturers and retailers to develop effective category management processes.

Category Management recognizes the interrelatedness of products in a category and focuses on improving the performance of the whole category rather than the performance of individual brands (either private or national). Under Category Management, category managers are responsible for integrating procurement, pricing, and merchandising functions of all brands in a category and jointly developing and implementing category-based plans with manufacturers to enhance the outcomes of both parties (Pellet, 1994).

\section{PURPOSE OF THE STUDY}

This purpose of this study is to empirically investigate the influence of private label products by a supermarket retailer on category profitability. The supermarket retailer is located in the Northeast and operates over 100 stores that generate a total yearly sales volume in excess of $\$ 3$ billion. Private label brands, being exclusive brands, can allow retailers to differentiate themselves from competitors leading to a competitive advantage. As the emphasis on increasing private label sales continues to escalate, supermarkets need to understand fully the role of private brands in facilitating sources of a competitive advantage.

Supermarkets have an incentive to expand their private label offerings. A leading industry consultant in the supermarket industry states they "are most interested in differentiating themselves from other chains, and they view private label as a primary differentiator" (Cannondale Associates, 2001). A new Food Marketing Institute report encourages its supermarket members to market the retail store as a brand, and an industry consultant cautions that maintaining a competitive advantage requires building stronger private label programs rather than simply "selling other people's brands" (Steiner, 2004).

Category management objectives seek to maximize sales and profits of the entire product category utilizing the entire product assortment mix and not just focusing on a particular brand. It is vital for businesses to focus on all category brands and not over-emphasize any particular brand.

The purpose of this study is to focus on the longitudinal effects of changes in private label category sales on overall category profitability. The focus of the study is at the product category level. Category specific changes in overall private label sales penetration are studied to determine the impact on overall category profitability. For example, does increasing the private label sales in a product category such as ice cream result in increasing total ice cream category profitability? 


\section{JUSTIFICATION OF THE STUDY}

Most supermarkets have embraced a new process strategy called category management which shifts the manager's focus from individual brands to the overall performance of the category since its inception in the early 1990's (Nelson \& Desrochers, 2006). Concurrent with the rapid adoption of category management practices in the last fifteen years by supermarkets has been the increased emphasis on increasing private label sales. Since private brands are exclusive to supermarkets, they may be instrumental in generating a sustainable competitive advantage.

Some researchers have questioned if increasing private label sales results in growing overall category profitability. Ailawadi and Harlam (2004) doubt the assumption of private label products being more profitable because although the profit margins for store brands may be higher, dollar unit profits are not necessarily higher for store brands. Increasing store brand shares can lead to lower total overall profits and even greater revenue loss if the increase in store brand share is not accompanied by greater spending at the store. Corstjens and Corstjens (1995) demonstrated that national brands are more profitable than private label brands when all factors such as deal allowances, warehousing, transportation and in-store labor were taken into account. In a study of saltine crackers conducted by Smith Barney (1995), the percentage margin was higher for the store brand but the penny profits lower. This could result in overall category sales declining as a result of the increase in private label sales. In a study of 60 food categories, almost half of the DOB (distributor-owned brand) products resulted in less profit per cubic meter than brand leader counterparts (Glement, 1995).

The literature has also presented the argument that an increase in store brand spending may be related to lower store loyalty (Sudhir \& Talukdar, 2004). Store brand customers have been found to be more price sensitive than average consumers in previous research (Dick et al., 1995). If purchasing private label brands is correlated with price sensitivity and deal proneness, a negative relationship could exist between both store brand patronage and store revenues and store brand patronage and profits due to "cherry picking" behavior across stores by deal prone consumers. This could lead to a lower share of overall spending at the store.

\section{METHODOLOGY}

Retailers mainly practice category management to increase profits and sales although different strategies may be pertinent for different categories. "Retailers practice category management with several ends in mind, but increasing profitability, increasing revenue and optimizing item mix are the most important motivators." Ninety seven percent of retailers, for example, surveyed indicated that the top priority for practicing category management is increased profitability (ACNielsen, 1998).

Store brand penetration growth in a large number of markets and their broader acceptance by consumers oblige suppliers to take an increased interest in their promotion. Retailers consider their private brands a powerful competitive tool allowing them to improve store image and obtain greater margins resulting in greater profits (Recio \& Roman, 1999).

An efficient and effective store brand program may not only increase market share in a store but is also an important tool in negotiations between distributors and manufacturers. Corstjens and Lal (2000) results indicate that there should be enough customers who buy national brands for a quality store brand strategy to be profitable. This balance between national and private label brands is in the best interest of consumers by ensuring a broad choice of products to choose from as well as low prices. The strength of private label brands keeps manufacturers in check by suggesting to them to offer competitive wholesale prices on national brands. The strength of national brand products keeps retailers in check by inducing them to compete with one another by offering competitive prices (Ailawadi, 2001).

The research questions developed for this study were based on previous research pertaining to category management and branding. Research questions and resulting hypothesis were developed based upon the literature and research by such authors as Nelson and Desrochers (2006), ACNielsen (2006), Harlow (1994), Dupre and Gruen (2004), and Jacoby and Chestnut (1978). These studies identified the overall objectives of category management and the significance of private brands in the overall category management process. 


\section{Research Questions}

Specifically, this study seeks to answer the following research questions related to achieving a superior category performance:

1. Is there a positive relationship between private label category sales and total category profitability?

2. Does the extensive focus of retailers in promoting their private brands conflict with the premise of category management that seeks to maximize the sales and profits of the entire category and not any individual brand?

\section{Hypotheses}

Based upon the research questions, the following hypothesis, stated in null and alternative form, will be tested in this study:

$\mathbf{H}_{10}$ : There is not a significant positive relationship between a Change in Category Specific Private Sales Label Penetration and Category Profitability.

$\mathbf{H}_{1 \mathbf{a}}$ : There is a significant positive relationship between a Change in Category Specific Private Label Sales Penetration and Category Profitability.

\section{Research Design Overview}

A Supermarket retailer located in the northeast was used for this research. This Supermarket has annual sales exceeding $\$ 3.0$ billion annually and places a major emphasis on the growth of their private label products. The Grocery Department consists of center store dry grocery, dairy and frozen foods sections and formed the sample for which secondary data was obtained. The supermarket retail chain has over 100 stores dispersed over New England states and is representative of typical United Sates national grocery markets.

Category management is implemented at this Supermarket retailer and data was obtained from 10 different product categories. The categories are divided based on consumer purchase patterns of similarities among products and key objectives of each category manager is to increase sales or profits of each category along with private label sales penetration.

\section{Data Collection}

All data for this research involved the use of secondary data. The hypothesis was tested by data obtained from the internal financial database of the Supermarket that is generated from point of sale information.

Point-of-sale (POS) scanner data provides a unique opportunity for analyzing consumer packaged goods trends and patterns by data mining techniques. Decisions of increased complexity are made possible by the amount of data available and marketing decision-making in the consumer packaged goods area benefits from advances in the collection of electronic scanner data. A critical problem facing today's consumer packaged goods brand managers is not a lack of data but a lack of systems transforming voluminous scanner data into decisions of strategic advantage (Jiang et al., 1998).

\section{Measurement of Variables}

1. Change in Category Specific Private Label Sales Penetration- A three year history from fiscal 2004-2006 by period (39 total periods) of Private label penetration for ten grocery product categories was analyzed from information gathered from the Supermarket's point of sale database. Private label category sales penetration is calculated as private label category sales divided by total category sales. The ten product categories analyzed were: Butter, Eggs, Milk, Flour, Sugar, Soup, Baby Diapers, Laundry Detergent, Cookies and Ice Cream. During the 39 time periods that the data was obtained, the average department private label sales 
penetration was $21.49 \%$. The first five categories selected (Butter, Eggs, Milk, Flour, Sugar) are commodity based with private label sales penetration exceeding the department average. The second five categories selected (Soup, Baby Diapers, Laundry Detergent, Cookies, Ice Cream) had private label sales penetration lower that the department average.

2. Category Profitability- A three year history from fiscal 2004-2006 by period (39 total periods) of Category Gross Profit dollars of each of the ten categories was gathered from the Supermarket's point of sale database.

\section{RESULTS}

Table 1 indicates the average private label sales penetration for each product category studied during the 39 periods. Also provided is the average department private label sales penetration of $21.49 \%$ for the same time frame. As previously indicated, the first five categories selected (Butter, Eggs, Milk, Flour, Sugar) are commodity based with private label sales penetration exceeding the department average. The second five categories selected (Soup, Baby Diapers, Laundry Detergent, Cookies, Ice Cream) had private label sales penetration lower that the department average.

Table 1: Average PL Sales Penetration Per Period and Department Average

\begin{tabular}{|l|c|c|}
\hline \multicolumn{1}{|c|}{ Category } & $\begin{array}{c}\text { Specific Category Average PL Sales } \\
\text { Penetration }\end{array}$ & $\begin{array}{c}\text { Department Average PL Sales } \\
\text { Penetration }\end{array}$ \\
\hline Butter & $65.55 \%$ & $21.49 \%$ \\
\hline Eggs & $77.06 \%$ & $21.49 \%$ \\
\hline Milk & $72.38 \%$ & $21.49 \%$ \\
\hline Flour & $32.11 \%$ & $21.49 \%$ \\
\hline Sugar & $52.55 \%$ & $21.49 \%$ \\
\hline Soup & $10.65 \%$ & $21.49 \%$ \\
\hline Baby Diapers & $13.98 \%$ & $21.49 \%$ \\
\hline Detergent & $6.31 \%$ & $21.49 \%$ \\
\hline Cookies & $9.00 \%$ & $21.49 \%$ \\
\hline Ice Cream & $20.55 \%$ & $21.49 \%$ \\
\hline
\end{tabular}

Correlation tests were generated for all ten product categories selected between category private label sales penetration and category profitability. The hypothesis stated that there is a significant positive relationship between a Change in Category Specific Private Label Sales Penetration and Category Profitability. Table 2 indicates the results of the correlation tests. Only two categories, eggs and laundry detergent, resulted in a significant positive relationship. This means that as private label sales increased in a product as a percentage of overall category sales, the total profitability of the category also increased. Four product categories (flour, sugar, soup, ice cream) resulted in a significant negative relationship indicating that category profitability decreased as private label sales penetration increased. The results did not differ between categories with less than average private label sale penetration and those that exceeded the department average.

Table 2: Correlations between PL Sales Penetration and Category Profitability

\begin{tabular}{|l|c|c|}
\hline \multicolumn{1}{|c|}{ Category } & Sig. (2 tailed) & Pearson Correlation \\
\hline Butter & .377 & -.146 \\
\hline Eggs & .001 & $.526^{* * *}$ \\
\hline Milk & .057 & -.308 \\
\hline Flour & .002 & $-.484^{* * *}$ \\
\hline Sugar & .000 & $-.569^{* * *}$ \\
\hline Soup & .000 & $-.552^{* * *}$ \\
\hline Baby Diapers & .069 & .294 \\
\hline Detergent & .010 & $.410^{* * *}$ \\
\hline Cookies & .935 & -.013 \\
\hline Ice Cream & .025 & $-.358^{* *}$ \\
\hline
\end{tabular}

Significant at .05 level

(C) 2012 The Clute Institute http://www.cluteinstitute.com/ 


\section{CONCLUSION}

The results of this study indicate the necessity for category managers to focus on all brands within their respective categories and not over-emphasize private label brands. Only two of ten product categories in this study exhibited a significant positive relationship between private label sales penetration and category profitability. Consumers prefer a full assortment of merchandise, and an over emphasis on private label brands may result in diminishing category performance. Category management stresses finding the optimal mix of all brands in a product category from the perspective of consumers and retailers' need to assess what this optimal level is for private label brands in each product category. Improved performance of the entire product category, and not just private label brands, is the underlying principle of category management practices.

Future research should incorporate marketing mix variables, such as pricing, promotional, and product elements. Average price disparity between national and private brands should be researched along with the frequency and magnitude of national and private label brand promotions for categories. Understanding the overall number of SKU's in a category and the percentage of private label items would enhance the awareness of the importance of product assortment mix.

\section{AUTHOR INFORMATION}

Michael Pepe is an Assistant Professor of Marketing and Management at Siena College in Loudonville, NY. After 20 years as a business professional in the retailing industry he became a full-time faculty member at Siena in 2009. His research interests include branding, consumer behavior, and pricing strategies. He has presented papers at the College Learning and Teaching Conference and Applied Business and Research Conference. He currently is the American Marketing Association student advisor at Siena College. E-mail: mpepe@ siena.edu

\section{REFERENCES}

1. ACNielsen (1998). Eighth Annual Survey of Trade Promotion Practices. Chicago: ACNielsen.

2. ACNielsen (2006). Consumer-Centric Category Management. Hoboken: Wiley and Sons.

3. Ailawadi, K., Neslin, S. \& Gedenk, K. (2001). Pursuing the value-conscious consumer: Store brands versus national brand promotions. Journal of Marketing, 65, 71-89.

4. Ailawadi, K. \& Harlam, B. (2004). An Empirical Analysis of the Determinants of Retail Margins: The Role of Store Brand Share. Journal of Marketing, 68, 147 -165.

5. Alaimo, D. (2003). More Sophisticated Private-Label Product. Supermarket News, 22, 36.

6. Cannondale Associates, Inc. (2001). Bridging the Gap. Category/Loyalty Management Survey, Wilton, CT.

7. Corstjens, J. \& Corstjens, M. (1995). Star Wars. West Sussex, England: John Wiley \& Sons.

8. Corstjens, M. \& Lal, R. (2000). Building Store Loyalty Through Store Brands. Journal of Marketing Research, 37, 281-291.

9. Dick, A., Jain, A., \& Richardson, P. (1995). Correlates of Store Brand Proneness: Some Empirical Observations. The Journal of Product \& Brand Management, 4, 15-22.

10. Dupre, K. \& Gruen, T. (2004). The use of category management practices to obtain a sustainable competitive advantage in the fast-moving-consumer-goods industry. The Journal of Business \& Industrial Marketing, 19, 444-459.

11. Garretson, J., Fisher, D., \& Burton, S. (2002). Antecedents of private label attitude and national brand promotion attitude: similarities and differences. Journal of Retailing, 78, 91-99.

12. Glement, F. (1995). How Profitable Are Arm Brand Products? McKinsey Quarterly, 3, 173-175.

13. Harlow, P. (1994). Category management: A new era in FMCG buyer-supplier relationships. Journal of Brand Management,2, 289-295

14. Hoch, S. (1996). How Should National Brands Think about Private Labels? Sloan Management Review, 37, 89-102.

15. Jacoby, J. \& Chestnut, R. (1978). Brand Loyalty Measurement and Management. New York: Wiley \& Sons.

16. Jiang, J., Klein, G. \& Pick, R. (1998). A marketing category management system: a decision support system using scanner data. Decision Support Systems, 23, 259-271. 
17. Levy, M. \& Weitz, B. (2007). Retailing Management. New York: McGraw Hill.

18. Nelson, P. \& Desrochers, D. (2006). Adding consumer behavior insights to category management: Improving item placement decisions. Journal of Retailing, 82, 357-365.

19. Patti, C. \& Fisk, R. (1982). National Advertising, Brands and Channel Control: An Historical Perspective with Contemporary Options. Journal of the Academy of Marketing Science, 10, 90-108.

20. Pellet, J. (1994, May). Category Management: Changing the Face of Retail. Discount Merchandiser, 34, 111-117.

21. PLMA yearbook, 2004.

22. PLMA yearbook, 2007.

23. Progressive Grocer (1995). Will Category Management Kill the Supermarket?

24. Quelch, J. \&Harding, D. (1996). Brand Versus Private Labels: Fighting to Win. Harvard Business Review, 74, 99-109.

25. Recio, M. \& Roman, M. (1999). Posibilidades de gestion de la marca de distributor. Distribucion y Consuma, 45, 13-29.

26. Richardson, P., Jain, A., \& Dick, A. (1996). Household Store Brand Proneness: A Framework. Journal of Retailing, 72, 159-185.

27. Steiner, R. (2004). The Nature and Benefits of National Brand/Private Label Competition. Review of Industrial Organization, 24, 105-127.

28. Sudhir, K. \& Talukdar, D. (2004). Does Store Brand Patronage Improve Store Patronage? Review of Industrial Organization, 24, 143-160.

29. Velez, J. (2003). Multiple Store Brands: An Empirical Investigation Of Consumer Perception. Unpublished master's thesis, The University of Guelph.

30. Wellman, D. (1997, October). Souping Up Private Label. Supermarket Business, 52, 13-20. 
NOTES 